\title{
MANAGEMENT OF TOMATO LATE-BLIGHT (PHYTOPHTHORA INFESTANS) THROUGH HOST PLANT RESISTANCE AND FUNGICIDE APPLICATION IN THE SUDAN-SAVANNAH NIGERIA
}

\author{
*Munkaila N.; Gaya A.G.; Lawan M.; Hamisu A.; Abdullahi A.; Suraja M. \\ Department of Crop Science, Faculty of Agriculture and Agricultural Technology, \\ Kano University of Science and Technology, wudil, P.M.B. 3244, Kano Nigeria \\ *Corresponding Author
}

DOI: https://doi.org/10.51193/IJAER.2021.7304

\begin{abstract}
A field experiment was conducted to determine the management of tomato late-blight through host plant resistance and fungicide application at Auyo and Buji during 2019/2020 dry season. The treatments consists of four tomato varieties (Rio-grande, UC-82B, Roma VF and Rukuta) and five fungicide (Ridomil-gold) frequencies (0,1,2 3 and 4 time spray), the unsprayed plots as a control and were laid out in a Split Plot Design where variety in the main plots while treatments (fungicide) in the sub-plots with three replications comprising of sixty (60) plots. The results were analyzed by ANOVA and the means were separated using Duncan's Multiple Range Test. The inoculation of the disease is by natural epiphytotics. Spraying of fungicides started at the first appearance of the disease and continues according to spray schedule at 10 days interval. Unsprayed plots were left as control for all varieties. During fungicide sprays, each plot was shielded with polyethylene sheets $3 \mathrm{~m}$ high on all sides of the plot to reduce inter-plot interference, i.e., to prevent the drift effect of the fungicide to the neighbouring plots. The parameters assessed and collected were; incidence of tomato late-blight, severity of tomato late blight, and yield ( $\mathrm{t} / \mathrm{ha}$ ). Integration of varieties and fungicide spray frequencies significantly reduced late blight epidemics and increased fruit yield. In both locations, severity was highest on the Rukuta variety and the lowest on the Rio-grande. The untreated plots of the four varieties were recorded with highest disease severity, while the lowest were recorded from plots treated with three and four time sprayed. There was a significant difference between the varieties and fungicide sprayed in both locations. In conclusion, integrations of varieties and 3-4 times Ridomil-gold sprays were found to be an effective treatment in reducing tomato late blight epidemics and increasing fruit yield. Thus it is recommended to use this spray level as it gave the highest protection against late blight and the highest monetary benefit as compared to the other
\end{abstract}


treatments and the control. The interaction between variety and fungicide sprayed were significantly difference in many parameters and were not significantly difference in some parameters in both locations. However, based on this research work, it is recommended to the farmers that for tomato late blight management, improved varieties should be use and be sprayed 3-4 times with appropriate fungicides for stable and profitable tomato production in Nigeria.

Keywords: Fungicide, Host Plant Resistance, Incidence, Late-blight disease, Severity, Yield

\section{INTRODUCTION}

Tomato (Lycopersicon esculentum Mill.) is one of the most important edible and nutritious vegetable crops in the world. It ranks next to potato and sweet potato with respect to world vegetable production. It is widely cultivated in tropical, sub-tropical and temperate climates and thus ranks third in terms of world vegetable production (FAO, 2006). It is widely accepted and commonly used in a variety of dishes as raw, cooked or processed products more than any other vegetable (Lemma, 2002).

It is one of the important cash-generating crops to small scale farmers and provides employment opportunity in the production and processing industries. It is also an important source of vitamin $\mathrm{A}$ and $\mathrm{C}$ as well as minerals. Such diverse uses made tomato an important vegetable in irrigated areas of agriculture in the country. It is a seasonal climbing plant of the family Solanaceae. It is grown as an annual produce for its fruits. It is one of the most popular and important vegetable for fresh consumption as well as processing. The plant requires a warm and dry climate. The optimum mean day temperature for growth of tomato lies between $21^{\circ} \mathrm{Cand} 26^{\circ} \mathrm{C}$ and temperature above $32^{\circ} \mathrm{C}$ during fruit development inhibit the formation of red color (MoA, 2012).

The leading tomato producing countries are China, the United State of America, India, Egypt, Turkey, Iran, Mexico, Brazil and Indonesia (FAO, 2006).

Tomato is an essential ingredient in the diet of the people and often used in almost every household. The fruit is fairly nutritious and contains high amount of vitamins A and C (AVRDC, 2004). Such diverse uses make tomato an important vegetable in irrigated agriculture in Ethiopia and the production is rapidly increasing in many parts of the country. Tomato is one of the most important and widely grown vegetable crop, both during the rainy and dry seasons for its fruit by smallholder farmers, commercial state and private farms (Emana, et al., 2014).

Production challenges for tomato crop include insect pests, diseases, weeds and harsh environmental conditions, like climate change. It is well known that diseases remain and pose the biggest challenges in tomato production. It is estimated that there are more than 200 known 
diseases affecting tomatoes worldwide. Tomato diseases are rampant in lowlands and highlands in the tropics and can cause 15 - 95\% crop loss (Jarvis and McKeen, 2013).Moreover, production of tomato is constrained due to shortage of high yielding varieties, low inputs, lack of appropriate postharvest technologies, inadequate technology transfer system, shortage of knowledge in utilization of the crop, poor marketing system, poor cultural practices, poor irrigation system and lack of responsible organization to multiply seeds of improved varieties, and these are additional productivity-limiting factors.

\section{MATERIALS AND METHODS}

\section{Experimental Sites}

The experiment was conducted during the dry season of 2019/2020 at Auyo and Buji Local government Areas of Jigawa State. Auyo Local Government Area is on the Latitude 9'59' 15.38' E and Longitude $12^{\circ} 22^{\prime}$ and $38.75^{\prime \prime} \mathrm{N}$, Buji Local government Area is on the Latitude $11^{\circ} 26^{\prime}$ and 59' ' N and Longitude 9०41' and 59' 'E.

\section{Treatments and Experimental Design}

The experiment consists of four tomato varieties: UC-82B, Roma VF, Rio-Grande, and Rukuta) with Five fungicide (Ridomil-gold) frequencies (0, 1, 2, 3, and 4 times spray), forming a total of 20 treatment combinations, including the control. Each treatment combination was assigned randomly to experimental units within a plot. The experimental design was split plot design where the varieties in the main plots while treatment fungicide in the sub-plots with three replications. The size of the experimental plot was $2 \mathrm{~m} \times 2.5 \mathrm{~m}\left(5.0 \mathrm{~m}^{2}\right)$. Each block were pegged and separated from each other by $1 \mathrm{~m}$ into 20 plots, there were five rows per plot and the middle three rows with a net area of $3 \mathrm{~m}^{2}$ (excluding the two border rows) were used for data collection.

\section{Seedling Raising}

The Seedlings for the field experiments were raised on four seed beds with width of the seed bed $2 \mathrm{~m} \times 2 \mathrm{~m}$ length for each variety. Width of walking area (path) between seed beds was $60 \mathrm{~cm}$. The seeds were sown at a depth of $0.5 \mathrm{~cm}$ in 10 rows with intra-row spacing of $15 \mathrm{~cm}$ in each bed. The beds were weeded and irrigated as deemed necessary.

\section{Transplanting}

Seedlings were transplanted at appropriate stage i.e. 28 days after sowing in 2019/2020 dry season respectively. Each replication was divided into 20 plots; each plot consists of 20 tomato stands. A spacing of $1 \mathrm{~m}$ and $2 \mathrm{~m}$ were used to separate each plot and block. Transplanting was 
done in five rows in each plot with spacing of $50 \mathrm{~cm} \times 50 \mathrm{~cm}$ between rows and plants within the row respectively.

\section{Fertilizer Application}

Two split doses of NPK 15:15:15 at 100kg/ha were applied at 2 week after transplanting and 2 weeks after the first application. The mode of fertilizer application was side placement at $5 \mathrm{~cm}$ apart.

\section{Disease Inoculation}

The inoculation of the disease is by natural epiphytotics.

\section{Treatment (fungicide)}

Spraying of fungicides was start at the first appearance of the disease and continues according to spray schedule at 10 days interval. Unsprayed plots were left as controls for all varieties. During fungicide sprays, each plot was shielded with polyethylene sheets $3 \mathrm{~m}$ high on all sides of the plot to reduce inter-plot interference, i.e., to prevent the drift effect of the fungicide to the neighboring plots. Weeding was done manually whenever necessary.

\section{Data Collection}

All the data were carefully observed and recorded, five tomato plants were selected at random from each plot, tagged for the disease severity and other parameters were taken at averaged. Disease incidence and severity were Arcsine transformed using the following formula;

$$
\text { Arcsine }=\sqrt{ } \mathrm{Y} \text { or } \sin ^{-1} \text {, where } \mathrm{Y}=\text { percent transformation. }
$$

The following parameters were assessed and collected:

\section{Percentage Disease Incidence of Tomato Late-blight}

The incidence of tomato late blight was recorded after the appearance of the disease symptoms on the crop by taking the percentage of plants showing symptoms of late blight. It is determined by counting the number of plants showing typical disease symptoms and expressed in percentage in relation to the total number of plants in each plot as follows:

Disease Incidence $(\%)=\frac{\text { Number of diseased plants }}{\text { Total number of plants observed }} \times 100$ 


\section{Percentage Disease Severity of Tomato Late -blight}

Tomato late blight disease severity was scored according to Maerere et al. (2010) on a scale of $1-4$ where; $1=0 \%$ (no symptoms on the leaf); $2=<10 \%$ leaf area infected and covered by spots (low/minor severity); $3=10-50 \%$ leaf area infected and covered by spots and also seen on petioles, branches, and stems (moderate severity) and $4=>50 \%$ leaf area infected and covered by spot, spots also seen on petioles, branches, stems and fruits (high/severely severity) The severity of tomato late blight was recorded by estimating the percentage of leaf area diseased on the 5 tagged plants at 1 week interval $(21,28,35,42$, and 49 days after transplanting) and expressed in percentage as follows:

Percentage disease severity $(S)=\frac{\text { Sum of numerical ratings }}{\text { Number of plants scored } x \text { maximum disease score on scale }} \times 100$

\section{Yield (ton/ha)}

All tomato fruits from the net plots were harvested and five samples from each plots were weighed using electric weighing balance to determine the yields which were later converted to yield (ton/ha).

\section{Data Analysis}

All data were subjected to statistical analysis of variance (ANOVA) as described by Snedecor and Cochran (1967). Means were separated using Duncan Multiple Range Test.

\section{RESULTS}

\section{Percentage disease incidence}

Management of tomato late-blight through host plant resistance and fungicide application on the percentage disease incidence is shown in Table 1. The result from the analysis of variance shows that, there was significant difference among varieties and fungicide sprays in both locations. Rukuta and Roma VF tomato has the highest percentage of disease incidence in both locations while UC-82B and Rio-Grande had least percentage disease incidence.

The result further shows that untreated plots (control) recorded the highest percentage disease incidence in both locations while tomato sprayed 3 and 4 had the least percentage disease incidence in both locations. There was interaction between variety and fungicide sprayed. The interaction shows that the untreated plots of the four varieties has the highest percentage disease incidence, followed by 1 time sprayed then 2 times sprayed, while spray of 3 and 4 times had the least percentage disease incidence in both locations (Table 2) 
International Journal of Agriculture and Environmental Research

ISSN: 2455-6939

Volume: 07, Issue: 03 "May-June 2021"

\section{Percentage disease severity}

Management of tomato late-blight through host plant resistance and fungicide application on the percentage disease severity is shown in Table 2. The result of the analysis of variance shows that there wasn't significant difference among the varieties at 21, 28, 35, and 42 days after transplanting at Auyo and 21, 28, and 42 days at Buji respectively. However, at 49 days after transplanting, Rukuta and UC-82B recorded the highest percentage disease severity while Riogrande variety had least disease severity in Auyo. At 35 and 49 days after transplanting, the result showed that Rukuta recorded the highest disease severity, followed by Rio-grande and UC-82B tomato varieties while Roma VF recorded the least disease severity at Buji.

The same Table shows that the untreated plots (control) recorded the highest disease severity, while, 3 and 4 times Ridomil-gold sprayed recorded the least disease severity in both locations. The interaction between variety and fungicide sprayed showed significant different, but in Auyo at 21 days showed no significant different while in Buji at 21 and 42 days showed no significant different. The interaction effect at 28, 35, and 49 days after transplanting shows that the control plots of the four varieties recorded the highest percentage disease severity, followed by 1 time sprayed, and subsequently 2 times sprayed, but the least was obtained from plots sprayed 3 and 4 times in both locations (Table 4, 5 and 6). At 42 days after transplanting, the interaction shows that there was no significant effect on both varieties with appropriate fungicide sprayed levels in Buji, but in Auyo shows that there was, and also the control plots of both varieties had the highest percentage disease severity while both varieties with sprayed of 3 and 4 times recorded the least percentage disease severity (Table 7). At 21 days after transplanting the interaction between varieties and fungicide sprayed shows no significant different in both locations.

\section{Yield (ton/ha)}

Management of tomato late blight through host plant and fungicide application on the yield (ton/ha) is shown in Table 8. Result shows that, the Rio-grande variety recorded with highest fruit yield, followed by UC-82B, then Roma VF, while Rukuta variety had the least yield in both locations.

The same Table also shows that, the used of 3 and 4 times Ridomil-gold gave the highest yield, followed by 2 times Ridomil-gold sprayed, then 1 time Ridomil-gold sprayed. The untreated (control) plots recorded with least yield in both locations. There were interaction effects between variety and fungicide sprayed. The interaction shows that plots sprayed 3 and 4 times of both varieties had the highest yield, followed by 2 times sprayed, then 1 time sprayed, while the least was obtained from the control plots at all sites (Table 9). 
International Journal of Agriculture and Environmental Research

ISSN: 2455-6939

Volume: 07, Issue: 03 "May-June 2021"

\section{DISCUSSION}

\section{Incidence and Severity of Tomato Late-blight}

In Auyo, mean late-blight incidence did not exceed $27.90 \%$ on Rio-grande, but reached up to $41.80 \%$ on Rukuta, $41.00 \%$ on Roma VF and $31.90 \%$ on UC-82B at final assessment date. Similarly, in Buji at final date of assessment mean late-blight incidences were recorded as $28.20 \%$ on Rio-grande, $55.70 \%$ on Rukuta, $41.97 \%$ on Roma VF, and $38.03 \%$ on UC-82B respectively. Among the fungicide sprays at the final date of assessment, the highest mean incidence such as $51.20 \%$, and $51.40 \%$ were recorded from unsprayed plots of all varieties in both locations, respectively. Similarly, at the same time, the lowest such as $33.70 \%, 33.43 \%$, $38.33 \%$ and $38.30 \%$ respectively were recorded from plots treated 3 and 4 times with Ridomilgold at 10 days interval on all varieties. As Berger (1988), Bedi, et al. (1989) and Fry and Shtienberg (1990) stated disease incidences among different varieties with reaction to diseases development variable and increase with time at the rates of epidemic much faster than disease severities for the same photo system under the same conditions. The maximum incidence for many photo systems is near $100 \%$ and this maximum commonly is reached early in the season, when severity may be low.

The severity of late-blight in current study showed that symptoms of tomato late-blight appeared prior to flowering stage and became more severe after flowering and fruiting stage for this particular pathogen, and this showed tomato plants were more susceptible at fruiting stage of the plant than early at the vegetative stage. This observation was in line with findings of Jones, et al., (1997) and Naveen kumar, et al., (2001) who stated that plants are more susceptible to infection by the pathogen during fruiting stage. Infected leaves began to defoliate starting two weeks after the appearance of symptoms on the plots severely attacked, especially in Buji. Jones (2007) also reported that infected leaves eventually withered, died and fell from the plant. In this present study, more defoliated leaves were observed on the untreated (control) plots than other plots treated with Ridomil-gold at 10 days interval on different varieties having different applications levels. The disease severity of late-blight in both locations was highly and significantly varied among the tomato varieties at all days of assessments. In both locations, it was highest on the Rukuta variety with (38.33\% in Auyo and 43.33\% in Buji). However, the lowest was recorded on the Rio-grande variety with $(31.67 \%$ in Auyo and $38.33 \%$ in Buji) respectively as at final assessment. This variation might be due to genetic differences among the varieties to resist the epidemics of late-blight and the environmental conditions of the surrounding during the experiment, there were higher temperature, wind speed, and low humidity in the growing period. The result of the current study coincided with the findings of Phillips, et al., (2005) who stated 
that if diversity is available for plant resistance against late-blight, the disease severity would be reduced if any given mixture or variety is grown.

In both locations, all Ridomil-gold sprays differed from the unsprayed (control) plots in reducing percentage disease severity at 10 days interval at different rates. Binyam, et al., (2014) reported that application of the fungicide significantly reduced disease severity. The mean severity of the plots treated with Ridomil-gold 3 and 4 times at 10 days interval ranged from the least the mean $25.00 \%$ for all the varieties. From the result, different foliar sprays of Ridomil-gold would be possible to deduce that 3 and 4 times foliar sprays of Ridomil-gold at 10 days interval could effectively reduce the magnitude of late-blight severity on each variety. Therefore, it is advisable to use this fungicide accordingly. The result of the present study was in conformity with the investigation of Abhinandan, et al., (2004) who reported that frequently applied fungicides by far reduced disease severity as compared to the less frequently sprayed fungicides and unsprayed plots.

\section{Yield (ton/ha)}

The highest yield (32.13 t/ha and $28.93 \mathrm{t} / \mathrm{ha})$ were obtained from Rio-grande and the least yield (18.60 t/ha and $16.13 \mathrm{t} / \mathrm{ha}$ ) were obtained from Rukuta variety in both locations. The lowest yield (16.25 t/ha and $14.33 \mathrm{t} / \mathrm{ha}$ ) were obtained from unsprayed plots while the highest yield (30.83 t/ha and $30.25 \mathrm{t} / \mathrm{ha})$ and (28.33 t/ha and $28.09 \mathrm{t} / \mathrm{ha})$ were obtained from treated plots 3 and 4 times with Ridomil-gold at 10 days interval. According to Dillard, et al., (1997), fungicide application was found to have a variable effect on yield. Abhinandan, et al., (2004) and kaushik, et al., (2011) who also reported that fungicide significantly reduced disease severity and gave increased yield over the control.

Table 1: Management of tomato late-blight through host plant resistance and fungicide application on the percentage disease incidence

\begin{tabular}{lc|c}
\hline Treatments & Auyo & Buji \\
\hline Variety & Disease incidence\% & Disease incidence\% \\
\hline Rio-rande & $27.90(0.28)^{\mathrm{c}}$ & $28.20(0.28)^{\mathrm{d}}$ \\
UC-82B & $31.90(0.32)^{\mathrm{b}}$ & $38.03(0.38)^{\mathrm{c}}$ \\
Roma VF & $41.00(0.41)^{\mathrm{a}}$ & $41.97(0.42)^{\mathrm{b}}$ \\
Rukuta & $41.80(0.42)^{\mathrm{a}}$ & $55.70(0.56)^{\mathrm{a}}$ \\
& $* *$ & $* *$ \\
SE \pm & 0.32 & 0.46 \\
\hline
\end{tabular}

\section{Fungicide Spray}

\begin{tabular}{lll}
\hline Ridomil-gold 0 time & $51.20(0.51)^{\mathrm{a}}$ & $51.40(0.51)^{\mathrm{a}}$ \\
\hline
\end{tabular}


International Journal of Agriculture and Environmental Research

ISSN: 2455-6939

Volume: 07, Issue: 03 "May-June 2021"

\begin{tabular}{lcc}
\hline Ridomil-gold 1 time & $46.73(0.47)^{\mathrm{b}}$ & $45.77(0.46)^{\mathrm{b}}$ \\
Ridomil-gold 2 times & $41.00(0.41)^{\mathrm{c}}$ & $41.97(0.42)^{\mathrm{c}}$ \\
Ridomil-gold 3 times & $33.70(0.34)^{\mathrm{d}}$ & $38.33(0.38)^{\mathrm{d}}$ \\
Ridomil-gold 4 times & $33.43(0.33)^{\mathrm{d}}$ & $38.30(0.38)^{\mathrm{d}}$ \\
& $* *$ & $* *$
\end{tabular}

SE \pm

0.16

0.43

INTERACTION

VXF

$* *$

$* *$

Means followed by the same letter within column are not significantly different according to Duncan's Multiple Range Test (DMRT), * = Significant at 5\% Probability level, $* *=$ significant difference at $1 \%$ probability level, $\mathrm{VXF}=$ interaction between variety and fungicide sprayed

Table 2: Interaction effect between variety and fungicide spray levels on the percentage incidence of tomato late-blight

Treatments

$\%$ Disease incidence Auyo

Fungicide levels
\% Disease incidence Buji Fungicide levels

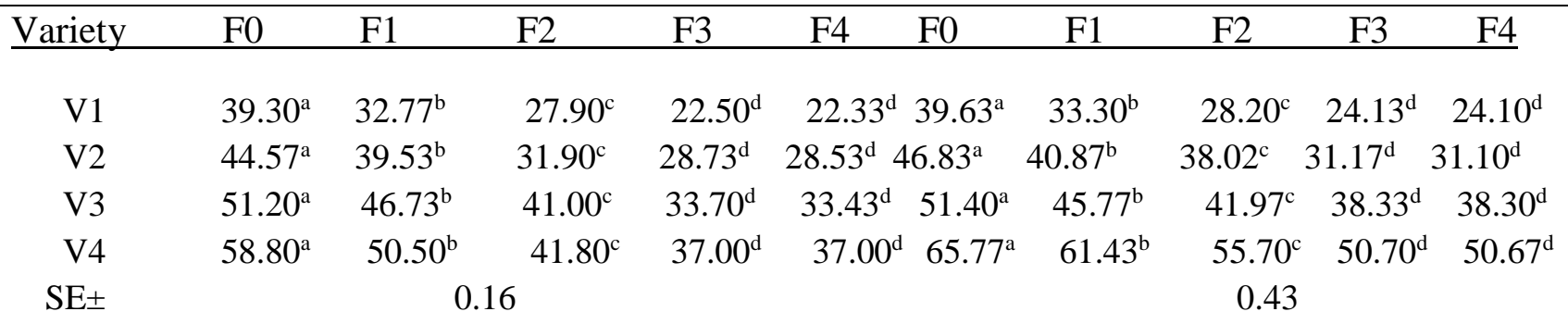

Means followed by the same letter within column are not significantly different according to Duncan's Multiple Range Test (DMRT), V1= Rio-grande variety, V2= UC-82B Variety, V3 = Roma VF variety, V4 = Rukuta variety, F0 = fungicide sprayed zero time, F1 = fungicide sprayed one time, F2 = fungicide sprayed two times, F3 = fungicide sprayed three times, F4 = fungicide sprayed four times. 
Table 3: Management of tomato late-blight through host plant resistance and fungicide application on the percentage disease severity

\begin{tabular}{|c|c|c|c|c|c|c|c|c|c|}
\hline \multicolumn{6}{|c|}{ Treatments \% Disease severity Auyo } & \multicolumn{4}{|c|}{ \%Disease severity Buji } \\
\hline Variety & 21 DAT & 28 DAT & 35 DAT & 42 DAT & 49 DAT 21 DAT & 28 DAT & 35 DAT & 42 DAT & 49 DAT \\
\hline Rio-rande4 & $0.00(0.40)$ & $35.00(0.35)$ & $31.67(0.32)$ & $30.00(0.30)$ & $31.67(0.32)^{b} \quad 43.33(0.43)$ & $38.33(0.38)$ & $35.00(0.35)^{\mathrm{ab}}$ & $33.33(0.33)$ & $38.33(0.38)^{b}$ \\
\hline UC-82B & $41.67(0.42)$ & $38.33(0.38)$ & $33.33(0.33)$ & $30.00(0.30)$ & $36.67(0.37)^{\mathrm{a}} \quad 43.33(0.43)$ & $40.00(0.40)$ & $35.00(0.35)^{\mathrm{ab}}$ & $30.00(0.30)$ & $38.33(0.38)^{b}$ \\
\hline ROMA VF & $41.67(0.42)$ & $36.67(0.37)$ & $35.00(0.35)$ & $30.00(0.30)$ & $35.00(0.35)^{\text {di }} 43.33(0.43)$ & $38.33(0.38)$ & $33.33(0.33)^{\mathrm{b}}$ & $33.33(0.33)$ & $33.33(0.33)^{c}$ \\
\hline \multirow[t]{2}{*}{ Rukuta } & $45.00(0.45)$ & $38.33(0.38)$ & $35.00(0.35)$ & $31.67(0.32)$ & $38.33(0.38)^{2} \quad 46.67(0.47)$ & $41.67(0.42)$ & $36.67(0.37)^{a}$ & $35.00(0.35)$ & $43.33(0.43)^{\mathrm{a}}$ \\
\hline & NS & NS & NS & NS & $* * \quad$ NS & NS & $* *$ & NS & $*$ \\
\hline SEt & 7.58 & 6.72 & 4.39 & 4.67 & 10.42 & 10.89 & 2.61 & 13.58 & 7.14 \\
\hline \multicolumn{10}{|c|}{ Fungicide Spray } \\
\hline Ridomil-gold 0 time & $48.33(0.48)^{2}$ & $51.67(0.52)^{a}$ & $56.67(0.57)^{2}$ & $61.67(0.62)^{\mathrm{a}}$ & $66.67(0.67)^{a} 53.33(0.53)^{a}$ & $58.33(0.58)^{2}$ & $63.33(0.63)^{a} 7$ & $71.67(0.72)^{\mathrm{a}}$ & $81.67(0.82)^{2}$ \\
\hline Ridomil-gold 1 time & $43.33(0.43)^{b}$ & $38.33(0.38)^{\mathrm{b}}$ & $33.33(0.33)^{b}$ & $40.00(0.40)^{\mathrm{b}}$ & $41.67(0.42)^{b} 48.33(0.48)^{b}$ & $43.33(0.43)^{\mathrm{b}}$ & $40.00(0.40)^{b}$ & $41.67(0.42)^{b}$ & $48.33(0.48)^{\mathrm{b}}$ \\
\hline Ridomil-gold 2 times & $41.67(0.42)^{b}$ & $36.67(0.37)^{b}$ & $35.00(0.35)^{b}$ & $30.00(0.30)^{\mathrm{c}}$ & $35.00(0.35)^{\mathrm{c}} 43.33(0.43)^{\mathrm{c}}$ & $38.33(0.38)^{c}$ & $33.33(0.33)^{c}$ & $33.33(0.33)^{c}$ & $33.33(0.33)^{c}$ \\
\hline Ridomil-gold 3 times & $38.33(0.38)^{c}$ & $33.33(0.33)^{c}$ & $30.00(0.30)^{c}$ & $25.00(0.25)^{d}$ & $25.00(0.25)^{d} \quad 40.00(0.40)^{d}$ & $35.00(0.35)^{\mathrm{c}}$ & c $30.00(0.30)^{d}$ & $25.00(0.25)^{d}$ & $25.00(0.25)^{\mathrm{d}}$ \\
\hline Ridomil-gold 4 times & $38.33(0.38)^{c}$ & $33.33(0.33)^{\mathrm{c}}$ & $30.00(0.30)^{c}$ & $25.00(0.25)^{d}$ & $25.00(0.25)^{d} \quad 40.00(0.40)^{d}$ & $35.00(0.35)^{c}$ & c $30.00(0.30)^{d}$ & $25.00(0.25)^{d}$ & $25.00(0.25)^{d}$ \\
\hline & ** & $* *$ & $* *$ & $* *$ & $* * \quad \quad * *$ & $* *$ & $* *$ & $* *$ & $* *$ \\
\hline $\mathrm{SE} \pm$ & 1.88 & 2.29 & 3.23 & 5.00 & 2.50 & 4.06 & 2.40 & 10.21 & 6.25 \\
\hline \multicolumn{10}{|l|}{ INTERACTION } \\
\hline vxf & NS & ** & $* *$ & ** & NS & $*$ & $* *$ & NS & $* *$ \\
\hline \multicolumn{10}{|c|}{$\begin{array}{l}\text { Means followed by the same letter within column are not significantly different according to Duncan's Multiple Range Test }\left(\text { DMRT), }{ }^{*}=\right. \\
\text { Significant at } 5 \% \text { Probability level, } * *=\text { significant difference at } 1 \% \text { probability level, DAT }=\text { days after transplanting, NS = Not Significant, VXF } \\
=\text { interaction between variety and fungicide sprayed }\end{array}$} \\
\hline www.ijaer.in & & Copyright & (C) IJAER 202 & 21 , All rights $\mathrm{r}$ & reserved & & & & Page 430 \\
\hline
\end{tabular}


International Journal of Agriculture and Environmental Research

ISSN: 2455-6939

Volume: 07, Issue: 03 "May-June 2021"

Table 4: Interaction effect between variety and fungicide spray levels on the severity of tomato late-blight disease at $\mathbf{2 8}$ days after transplanting

\begin{tabular}{ccc}
\hline Treatments & $\begin{array}{c}\text { Disease severity Auyo } \\
\text { Fungicide levels }\end{array}$ & $\begin{array}{c}\% \text { Disease severity Buji } \\
\text { Fungicide levels }\end{array}$
\end{tabular}

\begin{tabular}{|c|c|c|c|c|c|c|c|c|c|c|}
\hline Variety & F0 & $\mathrm{F} 1$ & F2 & F3 & F4 & F0 & F1 & F2 & F3 & $\mathrm{F} 4$ \\
\hline V1 & $48.33^{\mathrm{a}}$ & $38.33^{b}$ & $35.00^{\mathrm{c}}$ & $30.00^{\mathrm{d}}$ & $30.00^{\mathrm{d}}$ & $56.67^{\mathrm{a}}$ & $43.33^{b}$ & $38.33^{\mathrm{c}}$ & $33.33^{\mathrm{d}} 3$ & $33.33^{\mathrm{d}}$ \\
\hline V2 & $53.33^{\mathrm{a}}$ & $38.33^{b}$ & $38.33^{\mathrm{b}}$ & $33.33^{c}$ & $33.33^{\mathrm{c}}$ & $58.33^{\mathrm{a}}$ & $43.33^{\mathrm{b}}$ & $40.00^{c}$ & $33.33^{\mathrm{d}} 3^{3}$ & $33.33^{\mathrm{d}}$ \\
\hline V3 & $58.67^{\mathrm{a}}$ & $38.33^{b}$ & $36.67^{\circ}$ & $33.33^{\mathrm{d}}$ & $33.33^{\mathrm{d}}$ & $58.33^{\mathrm{a}}$ & $43.33^{b}$ & $38.33^{\circ}$ & $35.00^{\mathrm{d}}$ & $35.00^{\mathrm{d}}$ \\
\hline V4 & $58.33^{\mathrm{a}}$ & $41.67^{\mathrm{b}}$ & $38.33^{c}$ & $33.33^{\mathrm{d}}$ & $33.33^{\mathrm{d}}$ & $70.00^{\mathrm{a}}$ & $46.67^{b}$ & 41.67 & $36.67^{\mathrm{d}}$ & $36.67^{d}$ \\
\hline $\mathrm{SE} \pm$ & & & 6.72 & & & & & 4.06 & & \\
\hline
\end{tabular}

Means followed by the same letter within column are not significantly different according to Duncan's Multiple Range Test (DMRT), V1= Rio-grande variety, V2= UC-82B Variety, V3 = Roma VF variety, $\mathrm{V} 4=$ Rukuta variety, $\mathrm{F} 0=$ fungicide sprayed zero time, $\mathrm{F} 1=$ fungicide sprayed one time, $\mathrm{F} 2$ = fungicide sprayed two times, $\mathrm{F} 3$ = fungicide sprayed three times, F4 = fungicide sprayed four times.

Table 5: Interaction effect between variety and fungicide spray levels on the severity of tomato late-blight disease at 35 days after transplanting

\begin{tabular}{ccc}
\hline Treatments & $\begin{array}{c}\text { \%Disease severity Auyo } \\
\text { Fungicide levels }\end{array}$ & $\begin{array}{c}\% \text { Disease severity Buji } \\
\end{array}$ \\
& Fungicide levels
\end{tabular}

\begin{tabular}{|c|c|c|c|c|c|c|c|c|c|c|}
\hline Variety & F0 & F1 & F2 & F3 & F4 & F0 & F1 & F2 & F3 & F4 \\
\hline V1 & $50.00^{\mathrm{a}}$ & $35.00^{\mathrm{b}}$ & $31.67^{\mathrm{c}}$ & $25.00^{\mathrm{d}}$ & $25.00^{\mathrm{d}}$ & $61.67^{\mathrm{a}}$ & $40.00^{b}$ & $35.00^{c}$ & $30.00^{\mathrm{d}}$ & $30.00^{\mathrm{d}}$ \\
\hline V2 & $58.33^{\mathrm{a}}$ & $33.33^{\mathrm{b}}$ & $33.33^{b}$ & $28.33^{c}$ & $30.00^{c}$ & $63.33^{\mathrm{a}}$ & $40.00^{\mathrm{b}}$ & $35.00^{c}$ & $33.33^{d}$ & $30.00^{\mathrm{d}}$ \\
\hline V3 & $56.67^{\mathrm{a}}$ & $35.33^{\mathrm{b}}$ & $33.00^{c}$ & $30.00^{\mathrm{d}}$ & $30.00^{\mathrm{d}}$ & $63.33^{\mathrm{a}}$ & $40.00^{\mathrm{b}}$ & $33.33^{\mathrm{c}}$ & ${ }^{c} 30.00^{d}$ & $30.00^{\mathrm{d}}$ \\
\hline V4 & $63.33^{\mathrm{a}}$ & $35.00^{\mathrm{b}}$ & $35.00^{\mathrm{b}}$ & $30.00^{c}$ & $30.00^{\mathrm{c}}$ & $75.00^{\mathrm{a}}$ & $41.67^{b}$ & $36.67^{c}$ & c $30.00^{\mathrm{d}}$ & $30.00^{d}$ \\
\hline $\mathrm{SE} \pm$ & & & 3.23 & & & & & 2.40 & & \\
\hline
\end{tabular}

Means followed by the same letter within column are not significantly different according to Duncan's Multiple Range Test (DMRT), V1= Rio-grande variety, V2= UC-82B Variety, V3 = Roma VF variety, $\mathrm{V} 4=$ Rukuta variety, $\mathrm{F} 0=$ fungicide sprayed zero time, $\mathrm{F} 1=$ fungicide sprayed one time, $\mathrm{F} 2=$ fungicide sprayed two times, $\mathrm{F} 3$ = fungicide sprayed three times, F4 = fungicide sprayed four times. 
Table 6: Interaction effect between variety and fungicide spray levels on the severity of tomato late-blight disease at $\mathbf{4 2}$ days after transplanting in Auyo

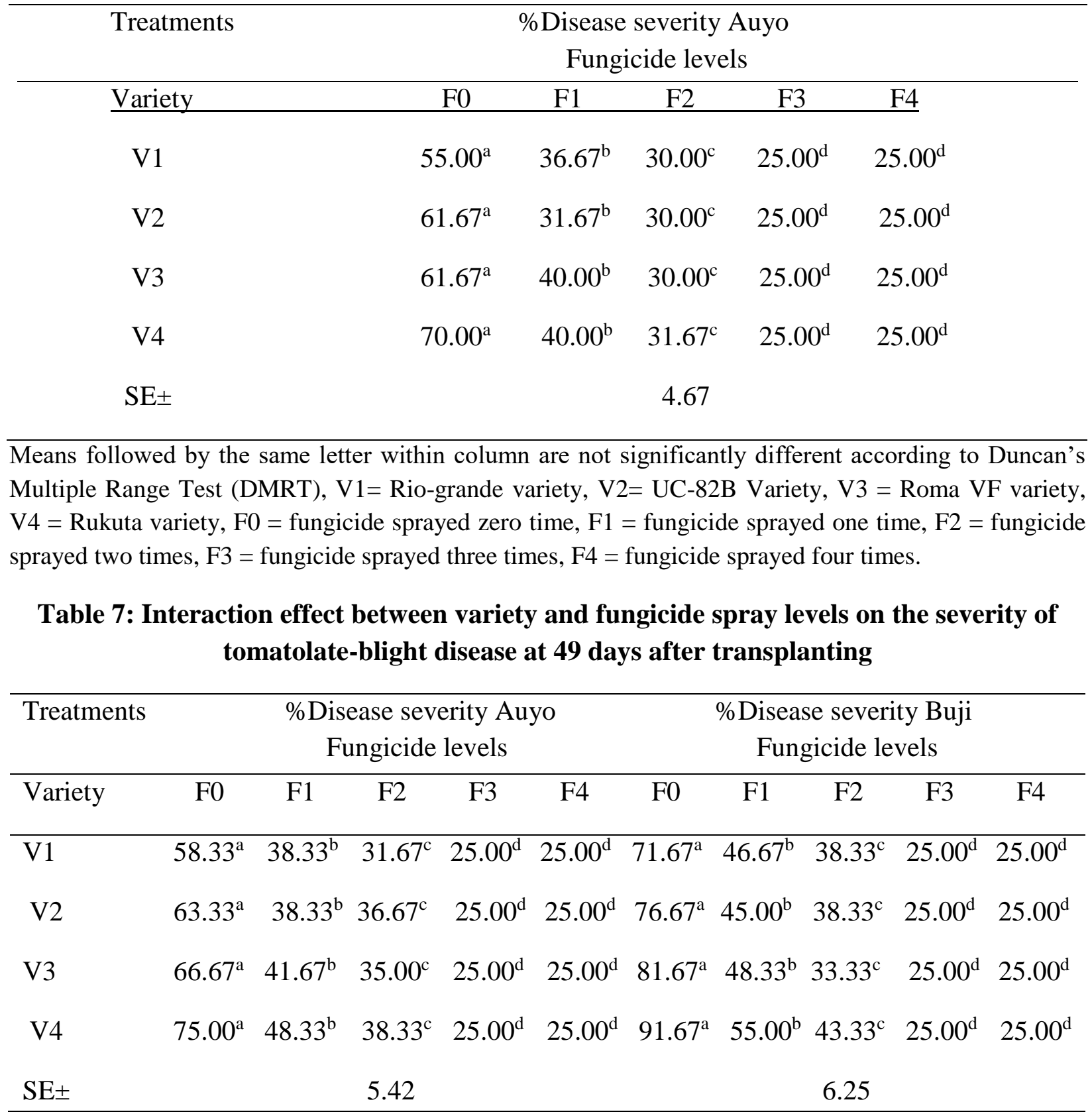

Means followed by the same letter within column are not significantly different according to Duncan's Multiple Range Test (DMRT), V1= Rio-grande variety, V2= UC-82B Variety, V3 = Roma VF variety, V4 = Rukuta variety, F0 = fungicide sprayed zero time, F1 = fungicide sprayed one time, F2 = fungicide sprayed two times, $\mathrm{F} 3$ = fungicide sprayed three times, $\mathrm{F} 4=$ fungicide sprayed four times. 
Table 8: Management of tomato late-blight through host plant resistance and fungicide application on the yield (ton/ha)

\begin{tabular}{|c|c|c|}
\hline Treatments & Auyo & Buji \\
\hline Variety & Yield (ton/ha) & Yield (ton/ha) \\
\hline Rio-Grande & $32.13^{\mathrm{a}}$ & $28.93^{\mathrm{a}}$ \\
\hline UC-82B & $25.81^{\mathrm{b}}$ & $23.20^{\mathrm{b}}$ \\
\hline Roma VF & $21.00^{c}$ & $19.80^{\mathrm{c}}$ \\
\hline \multirow[t]{2}{*}{ Rukuta } & $18.60^{\mathrm{d}}$ & $16.13^{\mathrm{d}}$ \\
\hline & $* *$ & $* *$ \\
\hline S.E \pm & 9.07 & 7.04 \\
\hline \multicolumn{3}{|l|}{ Fungicide Spray } \\
\hline Ridomil-gold 0 time & $16.25^{\mathrm{d}}$ & $14.33^{\mathrm{d}}$ \\
\hline Ridomil-gold 1 time & $20.17^{\mathrm{c}}$ & $17.00^{\mathrm{c}}$ \\
\hline Ridomil-gold 2 times & $24.50^{\mathrm{b}}$ & $22.33^{\mathrm{b}}$ \\
\hline Ridomil-gold 3 time & $30.25^{\mathrm{a}}$ & $28.08^{\mathrm{a}}$ \\
\hline Ridomil-gold 4 times & $30.83^{\mathrm{a}}$ & $28.33^{\mathrm{a}}$ \\
\hline & $* *$ & $* *$ \\
\hline S.E \pm & 6.18 & 4.56 \\
\hline
\end{tabular}

\section{INTERACTION}

VXF $* *$

$* *$

Means followed by the same letter within column are not significantly different according to Duncan's Multiple Range Test (DMRT), * = Significant at 5\% Probability level, ** = significant difference at $1 \%$ probability level

Table 9: Interaction effect between variety and fungicide spray levels on the yield ton/ha

\begin{tabular}{lccccccccccc}
\hline Treatments & \multicolumn{4}{c}{ Yield t/ha Auyo } & \multicolumn{5}{c}{ Yield t/ha Buji } \\
Vungicide levels & \multicolumn{5}{c}{ Fungicide levels } \\
V1 & $21.00^{\mathrm{d}}$ & $24.67^{\mathrm{c}}$ & $31.33^{\mathrm{b}}$ & $41.33^{\mathrm{a}}$ & $42.33^{\mathrm{a}}$ & $18.33^{\mathrm{d}}$ & $22.33^{\mathrm{c}}$ & $26.33^{\mathrm{b}}$ & $38.67^{\mathrm{a}}$ & $39.00^{\mathrm{a}}$ \\
V2 & $16.67^{\mathrm{d}}$ & $21.00^{\mathrm{c}}$ & $27.33^{\mathrm{b}}$ & $32.00^{\mathrm{a}}$ & $32.33^{\mathrm{a}}$ & $15.33^{\mathrm{d}}$ & $17.67^{\mathrm{c}}$ & $24.00^{\mathrm{b}}$ & $29.33^{\mathrm{a}}$ & $29.67^{\mathrm{a}}$ \\
V3 & $14.67^{\mathrm{c}}$ & $20.00^{\mathrm{b}}$ & $20.00^{\mathrm{b}}$ & $24.67^{\mathrm{a}}$ & $25.67^{\mathrm{a}}$ & $13.00^{\mathrm{d}}$ & $15.33^{\mathrm{c}}$ & $22.33^{\mathrm{b}}$ & $24.00^{\mathrm{a}}$ & $24.33^{\mathrm{a}}$ \\
V4 & $12.67^{\mathrm{d}}$ & $15.00^{\mathrm{c}}$ & $19.33^{\mathrm{b}}$ & $23.00^{\mathrm{a}}$ & $23.00^{\mathrm{a}}$ & $10.67^{\mathrm{d}}$ & $12.67^{\mathrm{c}}$ & $16.67^{\mathrm{b}}$ & $20.33^{\mathrm{a}}$ & $20.33^{\mathrm{a}}$ \\
\hline
\end{tabular}


International Journal of Agriculture and Environmental Research

ISSN: 2455-6939

Volume: 07, Issue: 03 "May-June 2021"

\section{SE \pm}

5.73

2.73

Means followed by the same letter within column are not significantly different according to Duncan's Multiple Range Test (DMRT), V1= Rio-grande variety, V2= UC-82B Variety, V3 = Roma VF variety, V4 = Rukuta variety, F0 = fungicide sprayed zero time, F1 = fungicide sprayed one time, F2 = fungicide sprayed two times, F3 = fungicide sprayed three times, F4 = fungicide sprayed four times.

\section{CONCLUSION}

In both locations, the studies concluded that Rio-grande and UC-82B varieties appeared to be comparative resistant to late-blight and are the promising tomato varieties. Further investigation should be carried out to verify whether it has a real genetic resistance; until that moment comes, those varieties can be used in combination with other management measures, wherever the disease is a pressing problem. Also the use of 3 and 4 times Ridomil-gold sprayed controlled the late-blight diseases.

\section{ACKNOWLEDGEMENT}

Appreciation is expressed to prof. Abba Garba Gaya for technical assistance in carrying out this research and by my mother Late Fatima lawanmunkaila for funding, may your soul rest in Jannatul Firdausameen.

\section{REFERENCES}

Abhinandan, D. M, Randhawa, H. S. and Shama, R. C. (2004). Incidence of Alternaria leaf blight in tomato and efficacy of commercial fungicides for its control. Annual Biological Science, 20: $211-218$.

AVRDC (Asian Vegetable Research and Development Center). (2004). The World Vegetable Center. Proceeding of the APSA-AVRDC workshop. May 6-7/ 2004. Shanhua, Taiwan. AVRDC Publication Number 05-619

Binyam, T., Temam H. and Tekalign T. (2014). Efficacy of reduced dose of fungicide sprays in the management of late blight (Phytophthora infestans) disease on selected potato (Solanum tuberosum L.) varieties, Haramaya, Eastern Ethiopia. Journal of Biology, Agriculture and Health Care, 4(20): 46 - 52.

Bedi, J. S., Thind, T. S., Grewal, R. K. and Sokhi, S. S. (1989). Role of application time of fungicides in the control of late-blight of potato. Plant Disease Resaerch, 4(2): $113-117$.

Berger, R. D. (1988). Measuring disease intensity. Special report: biological and cultural tests for control of plants diseases. American Phytopathology Society, 2:1 - 3. 
Chernet S., Belew D. and Abay, F. (2013). Genetic variability and association of characters in tomato (Solanum lycopersicon L.) genotype in Northern Ethiopia. International Journal of Agricultural Research, 8: 67 - 76.

Dillard, H. R., Johns, S. A., Cobb, A. C. and Hamilton, G. H. (1997). An assessment of fungicide benefits for the control of fungal diseases of processing tomatoes in New York and New Jersey. Plant Disease, 81: 677 - 681 .

Emani, A., Homayouni-Far, M., Razavi, R. and Eivazi, A. R. (2013). Introduction of superior tomato cultivars (Solanum lycopersicon Mill.). Journal of Food Science and Technology, 1: $19-26$.

Emana B., Ayana A., Balemi T. and Temesgen, M. (2014). Scoping study on vegetables seed systems and policy in Ethiopia.Final Report, Asian Vegetable Research and Development Center, Shanhua, Taiwan.

FAO (2006).FAO Production Year Book. Basic Data Unit, Statistics Division, FAO, Rome, Italy, No. 55, pp $125-127$

Fry, W. E. and Shtienberg, D. (1990). Integration of host resistance and fungicide to manage diseases.Canadian journal of Plant Pathology, 12:111 - 116.

Jarvis, W.R. and McKeen, C.D. (2013).Tomato Diseases, Hydro-Gardens. Agriculture Canada Publication, 75(1): $37-114$.

Jones, J. B., Jones J. P., Stall, R. E. and Zitter, T. A. (1997).Compendium of tomato diseases. American Phytopathology Society, pp: 28 - 29.

Jones, J.B. (2007). Tomato plant culture in the field, greenhouse and home garden. Chemical Rubber Company Press.USA, 420 pp.

Kaushik, S. K, Tomar, D. S. and Dixit, A. K. (2011). Genetics of fruit yield and its contributing characters in tomato. Sustainable Development. Journal of Agricultural Biotechnology, 310: $209-213$.

Lemma, D. (2002). Research experience and production prospects. ethiopian agricultural research organization (EARO), addis ababa Ethiopia, pp28.

Maerere A. P, Sibuga K. P, Bulali J. E, Mwatawala M. W, Kovach J, Kamanywa S, Mtui H. D, Erbaugh M, J. (2010). Evaluation of tomato (Lycopersicon esculentum L.) genotypes for yield and yield component. Plant Sciences, (2010), 6(3): 663-676. 
MoA (Ministry of Agriculture) (2012). Animal and Plant Health Regulatory Directorate. Crop Variety Register, Issue No. 15. Addis Ababa, Ethiopia.

Naveenkumar, S., Saxena, R. P., Pathak, S. P. and Chauhan, S. K. S. (2001). Management of Alternaria leaf disease of tomato. Indian Phytopathology, 54: 508.

Phillips, S. L. Shaw, M. W. and Wolfe, M. S. (2005). The effect of potato variety mixtures on epidemics of late blight in relation to plot size and level of resistance. Annals of Applied Biology, 147(3): 245 - 252.

Snedecor G.W. and Cochran W.G. (1967). Statistical methods, $6^{\text {th }}$ edition, pp. 607. lowa State University Press, lowa, U.S.A. 